\title{
Evaluation of microfiltration for the treatment of spent cutting-oil
}

\author{
JJ Schoeman* and O Novhe \\ University of Pretoria, Department of Chemical Engineering, Water Utilisation Division, Pretoria, South Africa
}

\begin{abstract}
A pilot plant using ceramic microfiltration membranes which could be regularly back-flushed with air for fouling control was evaluated for the treatment of spent cutting-oil. It was found that membrane fouling could be effectively controlled with regular air back-flushes (every $3 \mathrm{~min}$ for $1 \mathrm{~s}$ ) and chemical cleaning using caustic soda. Permeate flux remained approximately constant and varied from 78 to $126 \mathrm{l} / \mathrm{h} \cdot \mathrm{m}^{2}$ for the first six runs and from 114 to $150 \mathrm{l} / \mathrm{h} \cdot \mathrm{m}^{2}$ for three more runs. An increase in feed temperature from ambient to $40^{\circ} \mathrm{C}$ and cleaning of the membrane with $1 \%$ caustic soda, increased permeate flux from 183 to $282 \mathrm{\ell} / \mathrm{h} \cdot \mathrm{m}^{2}$ and from 195 to $264 \mathrm{\ell} / \mathrm{h} \cdot \mathrm{m}^{2}$ in two more runs. Excellent COD (75.5 to $\left.90.3 \%\right)$ and O\&G (97.2 to $\left.99.1 \%\right)$ removals were obtained. The permeate quality should be suitable for discharge to the municipal sewer system $(O \& G<500$ $\mathrm{mg} / \ell)$ and the concentrated oil should be a useful energy source. Treatment of spent cutting-oil with microfiltration rather than landfilling should save valuable landfilling space.
\end{abstract}

Keywords: spent cutting-oil, microfiltration, permeate flux, fouling, COD removal, O\&G removal

\section{Introduction}

Emulsified fluids are used to act as lubricants and coolants in metal-working operations to reduce friction between the metal and mechanical equipment, and to avoid metallic piece oxidation and contact welding of metal parts (Benito et al., 2002). After use, the fluids become less effective because of their thermal degradation and contamination by substances in suspension and therefore they must be replaced periodically, resulting in a waste stream called spent cutting-oil. It is claimed that spent cutting-oil emulsions are one of the largest wastewater volumes in metal-working industries. These emulsions must be treated before their disposal due to their detrimental effects on aquatic life and their interference with conventional wastewater treatment processes (Benito et al., 2002).

Spent cutting-oils are currently landfilled in South Africa. This practice, however, takes up space in landfill sites and the possibility exists that groundwater can be polluted in the process. The unintentional discharge of spent cutting-oils to the sewer system can affect biological treatment processes adversely. However, technologies are available that can be used for the treatment of spent cutting-oils to separate the oil from the water, to reduce the effluent volume and to improve the quality of the effluent significantly. These technologies include microfiltration(MF)/ultrafiltration(UF) (Zaidi et al., 1992; Benito et al., 1999; Benito et al., 2002; Fabish et al., 2001; Gryta et al., 2001; Jönsson and Trägârdh, 1990; Karakulski et al., 1998, Janknecht and Lopes, 2004; Benito et al., 2001; Chang et al., 2001; Siffert et al., 1994, Belkacem et al., 1994), settling (Kenneth, 1983), chemical treatment (Deepak et al., 1988), dissolved air flotation (Pushkarev et al., 1983), centrifugation (Bokotho et al., 1996), sorption processes (Silisio et al., 2002), hybrid ultrafiltration/membrane distillation(MD) (Gryta et al., 2001), membrane distillation (Gryta and Karakulski, 1999), reverse osmosis

* To whom all correspondence should be addressed.

喕 +27 12 420-3569; fax: +27 12 362-5089;

e-mail: japie.schoeman@up.ac.za

Received 16 May 2006; accepted in revised form 1 December 2006.
(Markind et al., 1974) and membrane bioreactors (Cheng et al., 2005).

Treatment of spent cutting-oils with MF and UF has shown that a relatively good quality permeate could be produced and that significant effluent volume reductions could be achieved (Zaidi et al., 1992; Gryta et al., 2001). Membrane fouling, however, remains a problem during the treatment of spent cutting-oils. Ceramic microfiltration membranes with regular air flushes and chemical cleaning under extreme $\mathrm{pH}$ conditions hold promise for the treatment of spent cutting-oils. However, little information is available in South Africa on the performance of ceramic microfiltration membranes for the treatment of spent cutting-oils. The objectives of this investigation were therefore to evaluate ceramic MF membranes for the treatment of spent cutting-oils.

\section{Experimental}

Spent cutting-oil was obtained from a glass-manufacturing company. The spent cutting-oil was pretreated by passing it through a $70 \mu$ bag filter to remove metal fines prior to MF treatment. The cutting-oil was then treated in batches $(150 \ell)$ in an MF pilot plant (Fig. 1) by passing it through a Membralox MF ceramic membrane $(0.1 \mu)$ module $\left(0.2 \mathrm{~m}^{2}\right.$ membrane area $)$ at an inlet

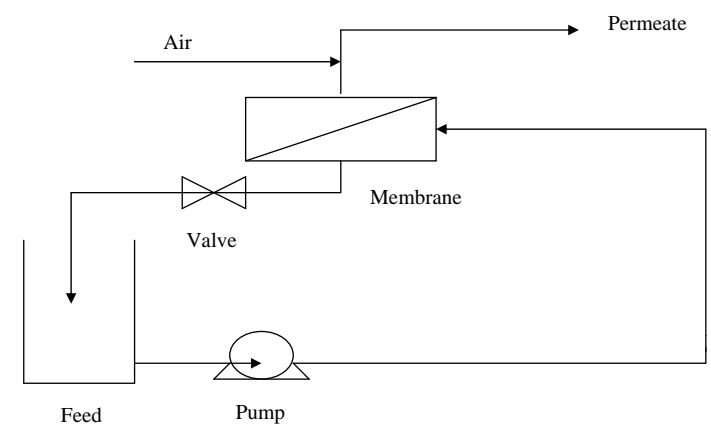

Figure 1

Simplified diagram of the experimental set-up for the MF treatment of the spent cutting-oil 


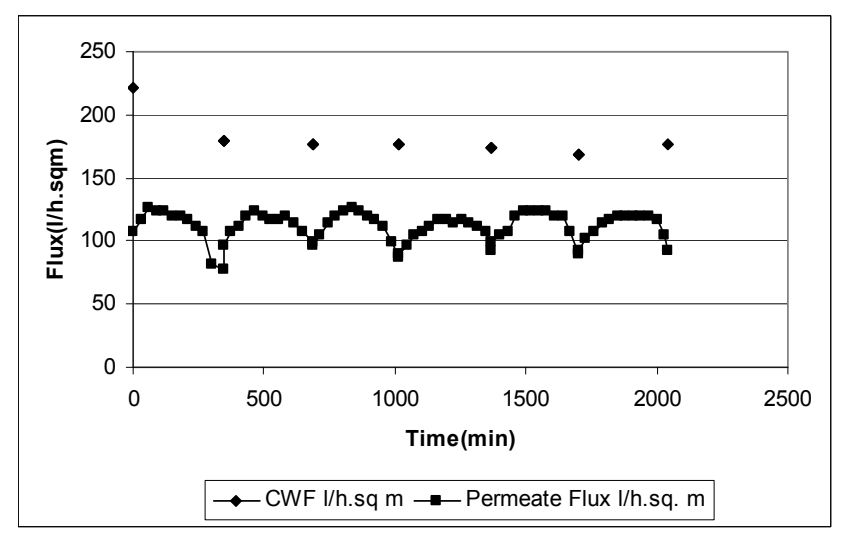

Figure 2a

Permeate and CWFs as a function of time during the MF treatment of the spent cutting-oil (Runs 1 to 6)

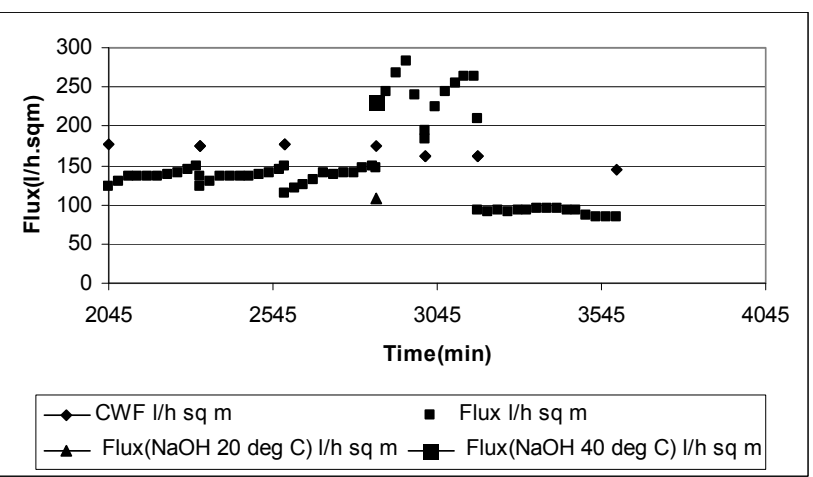

Figure $2 b$

Permeate and CWFs as a function of time during the MF treatment of the spent cutting-oil (Runs 7 to 12)

pressure of $400 \mathrm{kPa}$ and a flow rate of approximately $5250 \mathrm{\ell} / \mathrm{h}$ (Schoeman and Steyn, 1999). A compressed air back-flush was automatically carried out every $3 \mathrm{~min}$ for $1 \mathrm{~s}$ to control membrane fouling. The permeate flux, temperature and water recovery were measured as a function of time. The batch runs were terminated at approximately $87 \%$ water recovery. The COD and oil and grease $(\mathrm{O} \& \mathrm{G})$ concentration levels in the feed and composite permeate were determined at regular intervals.

All the batch runs, except two (approximately $40^{\circ} \mathrm{C}$ ) were conducted at ambient temperature. One batch run was also conducted at an inlet pressure of $300 \mathrm{kPa}$.

The clean water flux (CWF) was determined before and after the batch runs to determine the extent of membrane fouling. The membranes were cleaned with a $1 \%$ caustic soda solution as and when required.

\section{Results and discussion}

\section{Permeate flux during MF treatment of the spent cut- ting-oil}

The permeate and clean water fluxes as a function of time are shown in Figs. 2a and $b$.

The permeate flux for the first six batch runs remained fairly constant and varied between approximately 78 and 126 $\ell / h \cdot m^{2}$ (Fig. 2a). Note: No temperature control was applied and permeate flux increased as the result of a temperature increase by pumping and decreased as a result of fouling. The permeate flux then increased for the next three batch runs (Runs 7 to 9) and varied between approximately 114 and $150 \mathrm{\ell} / \mathrm{h} \cdot \mathrm{m}^{2}$ (Fig. 2b). This increase in permeate flux can be ascribed to a change in the composition of the spent cutting-oil sample used for the runs (new samples from the same source).

The average temperature during the 9 batch runs remained approximately the same for each run. Therefore, it appears that no significant membrane fouling had taken place. The temperature of the spent cutting-oil was increased to approximately $40^{\circ} \mathrm{C}$ for the next two batch runs (Runs 10 and 11) (Fig. 2b). Permeate flux varied between 183 and $282 \mathrm{l} / \mathrm{h} \cdot \mathrm{m}^{2}$ and between 195 and $264 \mathrm{\ell} / \mathrm{h} \cdot \mathrm{m}^{2}$ for the two runs, respectively. Therefore, permeate flux could be significantly increased by an increase in the feed temperature. This will result in a decrease in membrane area required and a reduction in capital cost. One run (Run 12) was conducted at an inlet pressure of $300 \mathrm{kPa}$. Permeate flux varied between 84 and $99 \mathrm{l} / \mathrm{h} \cdot \mathrm{m}^{2}$ during this run and was lower as a result of the lower applied pressure.

The CWF decreased from $222 \mathrm{l} / \mathrm{h} \cdot \mathrm{m}^{2}$ at the start of batch Run 1 to $180 \mathrm{l} / \mathrm{h} \cdot \mathrm{m}^{2}$ at the end of the run. The CWF then remained approximately constant between 168 and $177 \mathrm{l} / \mathrm{h} \cdot \mathrm{m}^{2}$ for Runs 2 to 9 . This indicates that very little membrane fouling had taken place during the batch runs. This can be ascribed to the compressed air back-flush which occurred every 3 min for $1 \mathrm{~s}$ during the batch runs. Membrane cleaning was conducted with a $1 \%$ caustic soda solution after Run 9. Cleaning at ambient temperature appeared to have no effect on the CWF; however, cleaning at approximately $40^{\circ} \mathrm{C}$ increased the CWF to $228 \mathrm{l} / \mathrm{h} \cdot \mathrm{m}^{2} \mathrm{com}-$ pared to $222 \mathrm{l} / \mathrm{h} \cdot \mathrm{m}^{2}$ at the start of the batch runs. Therefore, membrane fouling should be effectively controlled by cleaning with a $1 \%$ caustic soda solution at elevated temperature.

The CWFs dropped somewhat after Runs 10 and 11 and were lower after Run 12 (feed pressure $300 \mathrm{kPa}$ ). The COD of the feed during Run 12 was significantly higher than during the other runs (Table 1). Therefore, more membrane fouling could have taken place resulting in a lower CWF.

\section{COD and oil and grease concentration levels of the MF feed, permeate and brine}

The COD and O\&G concentration levels in the spent cutting-oil are very high. The COD concentration of the different feed samples varied between 12000 and $73800 \mathrm{mg} / \ell$ (Table 1). The COD of the permeate varied between approximately 2940 and 7430 $\mathrm{mg} / \ell(75.5$ to $90.3 \%$ COD removal). Therefore, the COD of the spent cutting-oil could be significantly reduced with MF treatment. The COD of the brine increased to $268000 \mathrm{mg} / \ell$ (Run 5).

Excellent O\&G removal was achieved during MF treatment of the spent cutting-oil. The $\mathrm{O} \& \mathrm{G}$ concentration in the feed varied between 13690 and $19794 \mathrm{mg} /$ land in the permeate between approximately 10 and $490 \mathrm{mg} / \ell$ ( 97.2 to $99.7 \%$ O\&G removal). Relatively high O\&G concentrations of between 320 and 490 $\mathrm{mg} / \ell$ were experienced in the MF permeate during Runs 5 to 9 . This could be ascribed to a change in the characteristics of the spent cutting-oil collected. The spent cutting-oil treated in Runs 5 to 9 had a different colour than previous and later samples collected, suggesting different oil characteristics. The $O \& G$ in the spent cutting-oil could be concentrated approximately 5.6 times (Run 5 from $17600 \mathrm{mg} / \ell$ in the feed to $98300 \mathrm{mg} / \ell$ in the retentate).

\section{Electrical conductivity and $\mathrm{pH}$ of the spent cutting-oil feed, permeate and brine}

The electrical conductivity of the feed and permeate varied between approximately 161 and $393 \mathrm{mS} / \mathrm{m}$ and 135 and 362 


\begin{tabular}{|c|c|c|c|c|c|c|c|c|}
\hline \multicolumn{8}{|c|}{ TABLE 1 } \\
COD and O\&G concentration levels of the spent cutting-oil feed, permeate and brine \\
during microfiltration treatment
\end{tabular}

\begin{tabular}{|c|c|c|c|c|c|c|c|}
\hline \multicolumn{8}{|c|}{$\begin{array}{c}\text { TABLE } 2 \\
\text { Conductivity and pH of the spent cutting-oil feed, permeate and brine } \\
\text { during microfiltration treatment }\end{array}$} \\
\hline \multirow[t]{2}{*}{ Run } & \multicolumn{2}{|c|}{ Feed } & \multicolumn{2}{|c|}{ Permeate } & \multicolumn{2}{|c|}{ Brine } & \multirow{2}{*}{$\begin{array}{l}\text { Conductiv- } \\
\text { ity } \\
\text { removal } \\
(\%)\end{array}$} \\
\hline & $\mathrm{pH}$ & $\mathrm{mS} / \mathrm{m}$ & $\mathrm{pH}$ & $\mathrm{mS} / \mathrm{m}$ & $\mathrm{pH}$ & $\mathrm{mS} / \mathrm{m}$ & \\
\hline 1 & 9.21 & 161 & 9.05 & 139 & 8.9 & 155 & 13.66 \\
\hline 2 & 7.86 & 226 & 8.94 & 163 & 8.74 & 181 & 27.88 \\
\hline 3 & 8.57 & 209 & 9.21 & 135 & 8.74 & 165 & 35.41 \\
\hline 4 & 8.75 & 164 & 9.02 & 138 & 8.27 & 236 & 15.85 \\
\hline 5 & 9.00 & 291 & 8.23 & 301 & 8.94 & 310 & - \\
\hline 6 & 8.93 & 304 & 9.10 & 285 & 9.08 & 318 & 6.25 \\
\hline 7 & 8.64 & 393 & 9.08 & 362 & 8.92 & 408 & 7.89 \\
\hline 8 & 8.41 & 190 & 8.86 & 161 & 8.52 & 228 & 15.26 \\
\hline 9 & 8.66 & 201 & 8.75 & 172 & 8.77 & 235 & 14.43 \\
\hline 10 & 8.39 & 323 & 8.62 & 288 & 8.42 & 352 & 10.84 \\
\hline 11 & 8.71 & 285 & 8.82 & 227 & 8.76 & 299 & 20.35 \\
\hline
\end{tabular}

$\mathrm{mS} / \mathrm{m}$, respectively (Table 2). It is interesting to note that salinity removal was achieved with MF treatment of the spent cutting-oil. Electrical conductivity removal as high as $27.9 \%$ was achieved in one case (Table 2). The salinity of the permeate should not have any adverse effect on biological treatment of the permeate.

The $\mathrm{pH}$ of the feed varied between 7.86 and 9.21. The $\mathrm{pH}$ of the permeate varied between 8.23 and 9.21 .

\section{Oil and grease removal from the MF permeate}

The current discharge requirements of O\&G into the municipal sewer system are $500 \mathrm{mg} / \ell$ (Bylaws 2004). However, this requirement might change to $100 \mathrm{mg} / \ell$ in future. Less than $500 \mathrm{mg} / \ell \mathrm{O} \& \mathrm{G}$ was obtained in the MF permeate. Therefore, MF should be a suitable technology for the treatment of spent cutting-oils if the treated effluent could be discharged into the municipal treatment system. However, MF should not be in a suitable technology if the O\&G concentration in the permeate should be less than $100 \mathrm{mg} / \ell$. Therefore, other methods were investigated in an attempt to reduce the $O \& G$ concentration in the MF permeate to lower levels (Schoeman and Steyn, 1999).
These methods include coagulation/flocculation, absorption, advanced oxidation processes, UF and MD. Of these methods, only activated carbon adsorption, UF and advanced oxidation processes could give O\&G concentration significantly lower than $100 \mathrm{mg} / \ell$. However, short-run lengths (activated carbon) and excessive dosages and membrane fouling (UF) would make these techniques ineffective. It was also shown that MD is an alternative technology that should reduce the O\&G concentration in the MF permeate to very low levels $(<10 \mathrm{mg} / \ell)$ (Gryta et al., 2001). This technology, however, appears to be expensive. Consequently, MF treatment of spent cutting-oil to reduce the O\&G concentration to less than $500 \mathrm{mg} / \ell$ and discharge into the municipal sewer system appears to be a suitable option for the handling of spent cutting-oils. This will save space in landfills and prevent possible groundwater pollution. The concentrated oil might also be a useful energy source.

\section{Conclusions}

- The MF permeate flux remained approximately constant during the batch treatment of the spent cutting-oil (78 to 126 $\mathrm{l} / \mathrm{h} \cdot \mathrm{m}^{2}$ for the first 6 runs and 114 to $150 \mathrm{l} / \mathrm{h} \cdot \mathrm{m}^{2}$ for the next 
3 runs). This indicates that membrane fouling should not be a serious problem.

- A temperature increase of the feed from ambient to $40^{\circ} \mathrm{C}$ and cleaning of the membranes with $1 \%$ caustic soda increased permeate flux from 183 to $282 \mathrm{l} / \mathrm{h} \cdot \mathrm{m}^{2}$ and from 195 to 264 $\ell / h . m^{2}$ for two runs

- The CWF declined initially and then remained constant. This also indicates that membrane fouling should not be a serious problem during treatment of spent cutting-oil with MF. The control of membrane fouling could be ascribed to the automatic compressed air back-flush of the membranes.

- Cleaning of the membrane with a $1 \%$ caustic soda solution at elevated temperature $\left(40^{\circ} \mathrm{C}\right)$ restored the CWF to its original value. This indicates that it should be possible to control membrane fouling with chemical cleaning.

- Very good COD removal (75.5 to 90.3\%) was obtained with the MF treatment of the spent cutting-oil

- Excellent O\&G removal (97.2 to $99.7 \%$ ) was also achieved with MF treatment. The O\&G concentration in the permeate varied between 10 and $490 \mathrm{mg} / \ell$.

- An O\&G concentration of less than $500 \mathrm{mg} / \ell$ in the MF permeate is currently satisfactory for discharge into the municipal sewer system. Therefore, MF treatment of spent cutting-oil should be a suitable technology for the treatment of spent cutting-oil for discharge into the municipal treatment system. This will save space in landfill operations and the retentate should be useful as an energy source. However, the discharge requirements might become stricter in future in which case other technologies like UF and MD should be considered for further treatment of the spent cutting-oil prior to discharge into the municipal system.

\section{Acknowledgements}

The very capable technical assistance of Mr. André Steyn is acknowledged.

\section{References}

BELKACEM M, MATAMORES H, CABASSUD C, AURELLE Y and COTTERET J (1994) A new step forward in the field of metal working waste water treatment using membrane technology. In: Proc. Engineering of Membrane Processes 11, Environmental Applications. 26 to 28 April 1994, Ciocco, Tuscany, Italy.

BENITO JM, RIOS G, ORTEA E, FERNANDEZ E, CAMBIELLA A, PAZOS C and COCA J (2002) Design and construction of a modular pilot plant for the treatment of oil-containing wastewaters. Desalination 147 (2002) 5-10.

BENITO JM, RIOS G, GUTIéRREZ B, PAZAS C and COCA J (1999) Integrated processes for the removal of emulsified oils from effluents in the steel industry. Sep. Sci. Technol. 34 (15) 3031-3043.

BENITO JM, EBEL S, GUTIéRREZ B, PAZAS C and COCA J (2001) Ultrafiltration of a waste emulsified cutting oil using organic membranes. Water Air Soil Pollut. 128 181-195.
BOKOTKO R, HUPKA J, LELINSKI D and MILLER JD (1996) Separation of oil-containing particles from water in a cyclone flotation machine. Environ. Sci. Res. 51 (1996) 155-164.

BYLAWS (2004) Ekurhuleni Metropolitan Municipality, 2 ${ }^{\text {nd }}$ Floor EGSC Building, Private Bag X1069, Germiston, 1400.

CHANG-IN SOUNG, CHUNG CHANG-MO and HON SEUNG-HO (2001) Treatment of oily wastewater by ultrafiltration and ozone. Desalination 133 225-232.

CHENG C, PHIPPS D and ALKHADDER RAFID M (2005) Treatment of spent metal working fluids. Water Res. 39 4051-4063.

DEEPAK D, ROY SG, RAGHAVAN K and MUKHERJEE S (1988) Effect of ferric chloride on the separation of miscible oil from wastewater. Indian J. Environ. Health 1 (1988) 43-49.

EGGBERRY I and SCHOEMAN JJ (1994) Evaluation of a combination of ultrafiltration and membrane distillation for the treatment of spent cutting-oils for pollution control. Laboratory Report, Department of Chemical Engineering, Water Utilisation Division, University of Pretoria.

FAIBISH RS and COHEN Y (2001) Fouling and rejection behaviour of ceramic and polymer-modified ceramic membranes for ultrafiltration of oil-in-water emulsions and micro-emulsions. Colloids and surfaces. Physicochem. Eng. Aspects 191 27-40.

GRYTA M and KARAKULSKI K (1999) The application of membrane distillation for the concentration of oil-water emulsions. Desalination 121 (1999) 23-29.

GRYTA M, KARAKULSKI K and MORAWSKI AW (2001) Purification of oily wastewater by hybrid UF/MD. Water Res. 35 (15) 36653669.

JANKNECHT P, LOPES AD and MENDES AM (2004) Removal of industrial cutting oil from oil emulsions by polymeric ultra- and microfiltration membranes. Environ. Sci. Technol. 38 4878-4883.

JÖNSSON AS and TRÄGÂRDH (1990) Ultrafiltration applications. Desalination 77 135-179.

KARAKULSKI K, MORAWSKI AW and GRZECHULSKA J (1998) Purification of bilge water by hybrid ultrafiltration and photocatalytic processes. Sep. Purif. Technol. 14 163-173.

KENNETH JL (1983) Demulsification: Industrial Applications. Marcel Dekker, New York, 1983.

MARKIND J, MINARD P, NERI J and STANA R (1974) Use of reverse osmosis for concentrating waste cutting-oils. AIChE Symp. Ser. 70 (144) (1974) 157-162.

PUSHKAREV VV, YUSHAMINOV AG and MEN SK (1983) Treatment of Oil-Containing Wastewaters. Allerton Press Inc., New York, 1983.

SCHOEMAN JJ and STEYN A (1999) Design and Operational Manual of a UF/MF Process for Treatment of Spent Cutting-Oils. Environmental Applications of Membrane Technologies. Contract report.

SIFFERT C, ELYASSINI J. NODARI T and MONCORGE G (1994) New membrane processes for oil water separation. In: Proc. Engineering of Membrane Processes 11, Environmental Applications. 26 to 28 April 1994, Ciocco, Tuscanny, Italy.

SOLISIO C, LODI A, CONVERTI A and DEL BORGHI M (2002) Removal of exhausted oils by adsorption on mixed $\mathrm{Ca}$ and $\mathrm{Mg}$ oxides. Water Res. 36 899-904.

ZAIDI A, SIMMS K and KOK S (1992) The use of micro/ultrafiltration for the removal of oil and suspended solids from oilfield brines. Wastewater Technol. Cent., Burlington, ON, Can. Water Sci. Technol. 25 (10, Membr. Technol. Wastewater Manage.), 163-176. Coden: WSTED4 ISSN: 0273-1223. 